\title{
Ortaokul Öğrencilerinin Sosyal Bilgiler Dersinde Çalışkanlık Değerine Yönelik Metafor Algiları
}

\author{
Vedat AKTEPE \\ Nevşehir Hacı Bektaş Veli Üniversitesi \\ vedataktepe@nevsehir.edu.tr \\ ORCID: 0000-0001-5259-9340 \\ Abdulkadir UZUNÖZ \\ Nevşehir Hacı Bektaş Veli Üniversitesi \\ a.uzunoz@nevsehir.edu.tr \\ ORCID: 0000-0002-4130-4612 \\ İlhami SARIÇAM \\ Ankara İl Milli Eğitim Müdürlüğü \\ ilhamisaricam@hotmail.com \\ ORCID: 0000-0002-7430-2293
}

\begin{tabular}{lrr} 
Araştırma Makalesi & DOI: $10.31592 /$ aeusbed.660037 \\
\hline Geliş Tarihi: 16.12 .2019 & Revize Tarihi: 04.04.2020 & Kabul Tarihi: 02.07.2020
\end{tabular}

\section{Atıf Bilgisi}

Aktepe, V., Uzunöz, A. ve Sarıçam, İ. (2020). Ortaokul öğrencilerinin sosyal bilgiler dersinde çalışkanlık değerine yönelik metafor algıları. Ahi Evran Üniversitesi Sosyal Bilimler Enstitüsü Dergisi, 6(2), 449-466.

\section{ÖZ}

Araștırmanın amacı 5, 6, 7 ve 8. sınıf öğrencilerinin Sosyal Bilgiler öğretimi programında yer alan "Çalışkanlık" değerine yönelik algılarını tespit etmek, metafor aracılığıyla bu algıyı sınıf ve cinsiyet düzeylerinde belirlemektir. Araştırmada nitel araştırma desenlerinden "Olgubilim" kullanılmıştır. Araştırmanın çalışma gurubu 2018-2019 eğitim-öğretim yılı bahar döneminde 5, 6, 7 ve 8. sınıfların dört şubesinden ikisi seçilmiş, sekiz şube üzerinden "Örnek Form ve Bireysel Bilgi Formu” aracılığıyla veriler toplanmıştır. Çalışma grubu 136 (68 kız - 68 erkek) öğrenciden oluşmaktadır. Ankara İli Sincan İlçesinde eğitim öğretime devam eden bir okulda 5, 6, 7 ve 8 . Sınıf öğrencilerinin çalışkanlık değerine yönelik görüşleri içerik analizi yöntemiyle analiz edilmiş ve elde edilen metaforlar uygun kategorilere ayrılarak belli temalar altında toplanmıştır. Sosyal Bilgiler Öğretimi Programında yer alan değerlerden "Çalışkanlık" değerine ilişkin öğrencilerin algılarını ortaya çıkarmak amacıyla "Çalışkanlık", "..............." ya benzer. Çünkü, “............." dır, şeklinde iki soru sorulmuş ve katılımcıların cevaplamaları istenmiştir. Araştırmada çalışkanlık değerine yönelik öğrenci görüşlerinden yapılan gruplamalarla "Mücadele, beklenti, sorumluluk, planlı olma ve düzen" kategorileri oluşturulmuştur. Yine araştırmada çalışkanlık değerine yönelik "Karınca, arı, azim, başarı, kitap, anne ve baba" metaforları ön plana çıkmıştır. Araştırmaya katılan 5.sınıf öğrencileri daha çok somut kavramları, 8.sınıflar ise daha çok soyut kavramları metafor olarak kullanmışlardır.

Anahtar Kelimeler: Öğrenci, metafor, Sosyal Bilgiler, çalışkanlık, değerler eğitimi.

\section{Secondary School Students' Metaphorıc Perceptions Towards The “Diligence” Value In Social Studıes Lesson}

\begin{abstract}
The aim of this study was to determine the perceptions of the 5th, 6th, 7th and 8th grade students towards the "diligence" value in the social studies education programme by means of metaphor according to their grades and genders. "Case Science",one of the qualitative research designs, was used in the study. The study group consisted of 136 students with 68 females and 68 males who attend the 5th, 6th, 7th and 8th grades in Sincan District of Ankara Province in the spring term of 2018-2019 academic year. In the research, interview form data were used as a data collection tool. Based on the opinions of the 5th, 6th, 7th and 8th grade students, the opinions of the students towards the "diligence" value were analyzed by content analysis method, and the metaphors obtained were collected under the appropriate categories. In order to reveal the metaphors about the "diligence" value of all the values included in the Social Studies Teaching Programme, a data collecting tool was created. Accordingly, Diligence is similar to "................" Because ".............." Two questions were asked in the form of a sentence, and the participants were asked to answer them. "Struggle, expectation, responsibility, being planned and order" categories were formed with the groupings made from the students' views on the "diligence" value. Again, the metaphors "ant, bee, perseverance, success, book, mother and father" have come to the fore in the study. When the data obtained from the research were evaluated, it was seen that the fifth grade students createmetaphors by using more concrete concepts, and the eighth grades create metaphors by using more abstract concepts.
\end{abstract}

Keywords: Student, metaphor, Social Studies, diligence, values education. 


\section{Giriş}

Eğitimin temel amacı kişilikli, donanımlı, yetiştiği toplumun değerlerini özümsemiş bireyleri yetiştirmek, toplumun refah ve huzuruna katkı sunmaktır. Bu maksatla ülkelerin eğitim politikaları yoluyla belirlenen ve eğitim sisteminin genel amaçları olarak kabul edilen hedefleri vardır. Hedeflenen insan modelinin sahip olması gereken tüm özellikler, bütün okul tiplerinde ve öğretim sürecinde dikkate alınarak yol gösterici olmalıdır. Toplumlar tarafindan oldukça önemli görülen hedefler, varılmak istenen özellikler olarak görülmektedir. Bu sebeple, bir toplum hangi eğitim hedefine ulaşmayı arzu ediyorsa o yönde değerler eğitimini uygulamak durumundadır. Şayet hedef, toplumsal kalkınmayı gerçekleştirebilmekse bilimsellik ve çalışkanlık gibi değerleri bu hedefe uygun olarak geliştirecektir (Güngör, 2000, s. 103). Eğitim programlarında yer alan çalışkanlık değerinin öğrencilere kazandırılması için, programlı öğrenmenin yanında aile ve çevreninde işe koşulması adeta amaç birliği oluşturacak şekilde okulların işbirliğine gitmesi gerekmektedir. Bu bağlamda bireylere değer kazandırma konusunda etki edebilecek tüm paydaşların veya bileşenlerin gözönünde bulundurulması ve işe koşulması gerekmektedir.

Okul kurum olarak, 1739 sayılı Millî Eğitim Temel Kanunu'nda yer alan Millî ve manevi değerlere saygilı, bedenen ve ruhen sağlıklı, yaşadığı topluma uyum sağlayan, aynı zamanda gelişime açık, devletin geleceği ve devamlılığını gaye edinmiş bireyler yetiştirme misyonuna sahiptir (Binbaşığlu, 1991). Bu paradigma içerisinde yerini alan sosyal bilgiler öğretim programında da aynı durum söz konusudur. Sosyal Bilgiler öğretim programı, öğrencilerin ilgi ve yetenekleri açısından kendilerine özgü oldukları anlayışını temel alarak, sınıfta, okulda, ailede, mahallede, toplumda ve uluslararası arenada değerlere sahip etkin bireyler olarak yetişmelerini sağlama amacı taşımaktadır.

Yaşadığımız çăg, teknolojinin hızlı ilerlemesine sahne olan, bilgi ve iletişimin iç içe olduğu, kültürler arasında var olan etkileşim sınırlarının kalktığı ve daha hızlı etkileşimin kurulduğu, insanın ürettiği her şeyin çok çabuk tüketildiği bir çağ olduğu kabul edilmektedir. Hayatın hızlı tüketimi olay ve olguları çok çabuk ve hızlı yaşamamızda etkili olmuştur. Bu bağlamda kültürel etkileşimdeki bu hızlı değişmeler bazı toplumlar için fayda sağlarken bazı toplumlar içinde istenmeyen sonuçların doğmasına zemin hazırlamıştır. Kültürel etkileșimin yol açtığı bu istenmeyen sonuçların veya olumsuzlukların etkisini azaltmanın yolu, toplum ve bireyler arasındaki bağları güçlendiren adeta maya etkisi yapan değerlerin öğrenilerek davranış haline getirilmesi ile mümkün olabilir.

Değerlerin birey ve toplum açısından yarar sağlaması, sosyal bilgiler öğretim programında yer alan değerler eğitimi yaklaşımlarının temel beklentisidir. Programda sınıf düzeylerine göre değerlerin istenilen düzeyde kazandırılabilmesi için, öğrencilerin ihtiyaç, ilgi ve yeteneklerinin dikkate alınması önemlidir (Aktepe, 2010). Ülkemizde 2005 programıyla birlikte değerler ve hangi değerlerin eğitiminöğretim sürecinde verilmesi gerektiğine yer verilmiştir. Ancak bu değerlerin nasıl verilmesi ve ne tür etkinliklerle kazandırılması gerektiğine pek fazla değinilmemiştir. Oysa, etkili bir değerler eğitiminde uygun olan yaklaşım, strateji, yöntem ve teknikler ortaya konulmalı, daha sonra uygulamada çocuğun gerçek yaşamıyla ilişkili etkinliklere yer verilerek, zengin bir öğrenme-öğretme süreci ile desteklenmeli ve uygun bir ölçme ve değerlendirme yöntemiyle sonuçlandırılmalıdır. Bu bağlamda yenilenen öğretim programlarında bireylerin yetiştirilmesinde, bilgi, beceri ve davranışlarla donatılmasında yeni öğretim yaklaşımları sunulmuşsa da uygulama boyutunda birçok sorun ortaya çıkmaktadır (Aktepe ve Tahiroğlu, 2016). Çünkü öğrencilere kazandırılacak olan değerler hakkında bireylerin düşüncelerine ya da algılarına dikkat etmeden onların sorunlarını belirleyebilmek, bu sorunları anlamak ve bu sorunlara çözümler üretmek güçtür. Bu durumda bireyin sorunlar karşısında kendi başına hareket ederek bu sorunlarla baş edebilir hale gelmesi daha da zorlaşmaktadır (Başaran, 2004; Akt. Kunduroğlu, 2010).

Sosyal Bilgiler dersi öğretim programında yer alan değerler incelendiğinde: Aile birliğine önem verme, adil olma, bağımsızlık, barış, özgürlük, bilimsellik, çalışkanlık, dayanışma, duyarlılık, dürüstlük, estetik, hoşgörü, misafirperverlik, sağlıklı olmaya önem verme, sayg1, sevgi, sorumluluk, temizlik, vatanseverlik, yardımseverlik değerlerinin yer aldığ 1 görülmektedir (Talim Terbiye Kurulu [TTK], 2010). 2018 yılında yayımlanan yeni sosyal bilgiler öğretim programında ise 10 tane kök 
değere yer verildiği görülmektedir: Adalet, dostluk, dürüstlük, öz denetim, sabır, sayg1, sevgi, sorumluluk, vatanseverlik ve yardımseverlik. Yine Millî Eğitim Bakanlığı'nın 2018 yeni Sosyal Bilgiler öğretimi programında 18 tane değerin verildiği görülmektedir: Bunlar; adalet, aile birliğine önem verme, bağımsızlık, barış, bilimsellik, çalışkanlık, dayanışma, duyarlılık, dürüstlük, estetik, eşitlik, özgürlük, sayg1, sevgi, sorumluluk, tasarruf, vatanseverlik, yardımseverlik olarak yer almaktadır (Millî Eğitim Bakanlı̆̆ [MEB], 2018). Bununla birlikte çalışkanlık değeri hem 2005 hem de 2018 programında yer alan ortak değerlerden biri olarak dikkati çekmektedir.

Çalışkanlığın kelime anlamı, "Çalışkan olma durumu, faaliyet" olarak tanımlanmaktadır (Türk Dil Kurumu, 2011). Bu durumda çalışkan bir bireye, "İşten kaçmayan ve çalışan kimse" diyebiliriz. Çalışkanlığın bir davranış olarak hem birey hem de eğitim için en önemli değerlerden biri olduğu söylenebilir. Hem mesleğinde hem yaşamında başarılı olan kişilere bakıldığında genellikle düzenli çalışan kişiler olduğu görülmektedir. Bu yüzden her öğretmen öğrencilerine çalışkanlık değerini kazandırarak onların başarılı olmalarını arzular. Çalışkan insanların sadece eğitim ve iş yaşamında değil sosyal hayatta da takdir edilen insanlar olduğunu çevremize baktı̆̆ımızda rahatlıkla görebiliriz.

Eski Türk Tarihi'ndeki Dede Korkut Hikâyeleri’nde çalışkanlık değerine özellikle sosyal yaşam içerisinde az da olsa rastlamak mümkündür (Gökyay, 1973, s. 311). Osmanlı döneminde Ahiler, aldıkları eğitim gereği gittikleri yerlerde iyilik, doğruluk ve çalışkanlık gibi özellikleriyle halkın gönlünü kazanarak, o beldeyi ordulardan önce fetih etmişlerdir. Ahi babalarının, esnaf kâhyalarının, ustaların, çırakların ve kalfaların bu başarıda büyük payı bulunmaktadır (Cora, 1990, s. 47).

Tarihsel açıdan bakıldığında yaşamda büyük önem verilen değerlerin okullarda öğretilmesi günümüz sorunlarının çözümüne katkı sağlayacağı düşünülmektedir. Okulların kullandığı öğreim programında bulunan değerlerin daha etkili kazandırılmasında öğrencilerin ilgi ve ihtiyaçlarını tespit etmek için birçok öğretim tekniği olmasıyla birlikte metafor tekniği öğrencilerin değerler hakkındaki algılarının ortaya çıkarılmasında önemlidir. Metaforlar da fikir ve davranışlara rehberlik eden yapılardır; öğrencilerin hayatı, nesneleri, çevreyi ve olayları farklı benzetmeler yoluyla nasıl değerlendirdikleri ve açıkladıklarıdır. Aynı zamanda metaforlar öğrencilerin düşüncelerinin zihinsel modellemeleridir (Aslan ve Bayrakçı, 2006; Cerit, 2008; Lakoff ve Johnson, 2005). Bu bağlamda metaforlar, öğrencinin zihninin belli bir kavrayış biçiminden başka bir kavrayış biçimine doğru yönelmesini sağlayarak o bireyin belli bir olguyu başka bir olgu olarak görmesine imkân tanırlar (Saban, 2009). Dolayısıyla öğrenciler, metaforları kullanarak bildikleri bir kavrama bildikleri üzerinden anlamlar yükleyerek veya nesneleri kullanarak açıklama yolunu seçerler. Sonuçta tanımlamaya çalıştıkları kavrama (değer) yönelik zihinlerinde önceden oluşturdukları kodlamaları veya ipuçlarını paylaşırlar.

Değer eğitimi ile ilgili alan yazın incelendiğinde; değerlere ilişkin metaforik alg1 üzerine çalışmalar yapıldığı görülmektedir (Akar, İnel ve Yalçıntaş, 2017; Aydın ve Sulak 2015; Balcı ve Yelken, 2013; Karadeniz, Er ve Tangülü, 2014; Gündüz, Saygılı ve Sulak, 2014; Yiğittir ve Kaymakçı 2012). Ayrıca Uzunöz, Aktepe ve Köybaşı (2018) değer analizi yoluyla dürüstlük değerini kazandırmaya yönelik bir çalışma yaparken, Yalman, Aktepe ve Uzunöz (2018) ahlaki ikilem tekniğine dayalı farklılıklara saygı değerini çalışmışlar, 7. sınıf öğrencilerin Kholbergin ahlak anlayışına göre düzeylerini tespit etmeyi amaçlamışlardır. Ulu Kalın ve Koçoğlu (2017) Sosyal Bilgiler öğretmen adaylarının bağımsızlık değerine karşı metaforik algıları isimli çalışmayı yürütmüşlerdir. Demirkaya ve Çal (2018) Sosyal Bilgiler öğretmen adaylarının dürüstlük değerine yönelik metaforik algıları üzerine bir çalışma yapmışlardır. Çelikkaya ve Seyhan (2017) Sosyal Bilgiler öğretmenlerinin ve öğretmen adaylarının evrensel değerlere ilişkin metafor algılarını tespit etmişler. Gömleksiz, Kan ve Öner (2012) Sosyal Bilgiler öğretmen adaylarının değer olarak demokrasi kavramına ilişkin metaforik algılarını çalışmışlardır. İnel, Urhan ve Ünal (2018) ortaokul öğrencilerinin adalet kavramına ilişkin metaforik algılarını tespit etmeyi amaçlamışlardır. Er Türküresin, Başer ve Yapıcı (2018) ortaokul öğrencilerinin dayanışma kavramına ilişkin algılarına yönelik metafor analizi çalışması yapmışlardır. Alan yazın değerlendirildiğinde metafor öğretimi için ahlaki ikilem ve değer analizi tekniğinden yararlanıldığı görülmektedir. Ayrıca ülkemizde değerlerle 
ilgili yapılan metafor çalışmalarına bakıldığında dürüstlük, saygı, bağımsızlık, evrensel değerler, demokrasi, adalet ve dayanışma değerlerinin olduğu görülmektedir. Öte yandan değerle ilgili algının tespitinde metafor tekniğinin yaygın olduğu görülmektedir. Çalışmalarda örneklem olarak; öğretmen adayları ve ortaokul öğrencilerinin seçildiği tespit edilmiş fakat çalışkanlık değerinin yer aldığ bir çalışmaya rastlanılmamıştır.

Eğitimin paydaşı ve nesnesi olan öğrencilerin değerler hakkındaki görüşleri, eğitim sistemi hakkında alınan kararlara ve uygulamalara projeksiyon sunacaktır. Bu sebeple çalışmada sosyal bilgiler öğretim programında yer alan "Çalışkanlık" değerine yönelik ortaokul öğrencilerinin metaforik algılarının tespit edilmesi ve bu metaforların sınıf düzeylerine ve cinsiyete göre farklılık gösterip göstermediği, sorusunun cevabı aranmaktadır.

Araştırmanın genel amacı; 5, 6, 7 ve 8 . sınıf öğrencilerinin sosyal bilgiler öğretimi programında yer alan "Çalışkanlık" değerine yönelik algılarını tespit etmek, sınıf ve cinsiyet düzeylerine göre farklılık gösterip göstermediğini belirlemektir. Literatür incelendiğinde ortaokul öğrencilerinin metafor yolu ile çalışkanlık değerine yönelik algılarını inceleyen çalışmalara rastlanmamıştır. $\mathrm{Bu}$ anlamda, ortaokul öğrencilerinin "Çalışkanlık" değerine yönelik algılarını metaforlarla nasıl ifade ettikleri bu araştırmanın önemini oluşturmaktadır. Araştırmanın amacına göre şu sorular cevap aranmıştır.

a) Öğrencilerin çalışkanlık değerine yönelik oluşan kategoriler nelerdir?

b) Öğrencilerin çalışkanlık değerine yönelik metaforları nelerdir?

c) Aynı sınıf öğrencilerinin çalışkanlık değerine yönelik metaforik algıları cinsiyete göre değişmekte midir?

d) Aynı sınıf öğrencilerinin çalışkanlık değerine yönelik metaforik algıları sınıf düzeyine göre değişmekte midir?

\section{Yöntem}

$\mathrm{Bu}$ araștırmada nitel araștırma desenlerinden "Olgubilim" kullanılmıștır. Olgubilim (fenomenoloji) deseni, farkında olduğumuz ama derinlemesine ve ayrıntılı bir anlayışa sahip olmadığımız olgulara odaklanmaktadır. Olgubilim, bize tümüyle yabancı olmayan aynı zamanda da tam anlamını kavrayamadığımız olguları araştırmayı amaçlayan çalışmalar için uygun bir araştırma zemini oluşturur (Yıldırım ve Şimşek, 2006). Araştırmada Sosyal Bilgiler öğretimi programında yer alan "Çalışkanlık" değerine ilişkin 5, 6, 7 ve 8. sınıf öğrencilerini metafor algıları içerik analizi yoluyla belirlenmiştir. Bu "Çalışkanlık" kavramına yönelik 5, 6, 7 ve 8. sınıf öğrencilerinin görüşlerinde "......" çünkü; “......." açıklamalarındaki ifade şekilleri temel alınarak kategoriler oluşturulmaya çalışılmıştır. Bu yöntemle, öğrencilerin çalışkanlık değeri hakkındaki düşüncelerini ayrıntılı olarak ortaya koymak amaçlanmıştır.

\section{Çalışma Grubu}

$\mathrm{Bu}$ araştırmanın çalışma gurubu, 2018-2019 eğitim-öğretim yılında Ankara ili Sincan ilçesinde bir okulda eğitim öğretime devam eden 5,6,7 ve 8. sınıf öğrencileri ile sınırlıdır. Okulun 5, 6, 7 ve 8 . sınıflarında var olan dörder şubeden ikişer şube seçilmiş, sekiz şube üzerinden "Örnek Form ve Bireysel Bilgi Formu" aracılığıyla veriler toplam 136 (68 kız - 68 erkek) öğrenciden toplanmıştır. Araştırmada, Yıldırım ve Şimşek'in (2006) de belirttiği gibi metaforlara bir konuda genelleme yapmak ve çeşitliliği sağlamak için değil, tam tersine çeşitlilik gösteren durumlar arasında ortak veya paylaşılan olguların olup olmadığını bulmaya çalışmak için başvurulur. Ayrıca metaforlara bu çeşitliliğe göre problemin farklı boyutlarını ortaya koymak için de başvurulmaktadır. Başvurulan örnekleme yöntemi Patton'a (1987) göre iki açıdan yararlıdır. Birincisi örnekleme ilişkin her durumun kendine özgü boyutlarıyla derinlemesine tanımlanabilmesi, ikincisi farklı özellik gösteren durumlar arasında ortaya çikabilecek ortak kategorileri belirleyebilmektir. 


\section{Veri Toplama Araçları}

Görüşme Formu: Çalışmada verileri toplamak için "Görüşme Formu” kullanılmıştır. Geliştirilen veri toplama formunda "Çalışkanlık" değerine ilişkin öğrencilerden "Görǚşme Formu" nu doldurmaları istenmiştir. Sosyal Bilgiler Öğretim Programı'nda yer alan değerlerden "Çalışkanlık" değerine ilişkin geliştirdikleri metaforları ortaya çıkarmak için Çalışkanlık, “..........” ya benzer. Çünkü, “............." dır. Cümlesi şeklinde araştırılan kavramlar soru şeklinde katılımcılara verilerek cevaplandırılması istenmiştir.

\section{Veri Toplama Aracı ve Verilerin Toplanması}

Verilerin toplanması sürecinde 5. sınıfdan başlanarak her gün bir sınıfa görüşme formu araştırmacılar tarafindan uygulanmıştır. Araştırmada 5, 6, 7 ve 8. sinıflarda toplam 136 öğrenciyle görüşülmüştür. Uygulama sürecinde görüşme formları dağıtılmadan önce öğrencilere gerekli açıklamalar yapılmıştır. Araştırmanın görüşme formu, hazırlama kategorilerin oluşturulması aşamalarında uzman görüşü alınmıştır. Görüşme formu oluşturulması aşamasında bir uzman görüşü, kategorilerin oluşturulması aşamasında bir uzman görüşü, araştırmanın tamamı hakkında iki uzman görüşü alınmış ve intihal kontrolü bir uzman tarafindan yapılmıştır.

\section{Verilerin Analizi}

Ortaokul öğrencilerinin "çalışkanlık” değeri algılarına yönelik metaforlar çünkü; “.........” dır. şeklinde belirtilmiştir. Bu bağlamda görüşme formundaki açıklamalar dikkate alınarak, anlam bütünlüğ̈̈ne göre kategoriler oluşturulmuştur. Verilerin analizinde frekans (f) değerlerine bakılmıştır. Yıldırım ve Şimşek (2006) araştırmada; insanlar ve durumlar hakkında detaylı ve daha zengin bilgiler üretilmesini sağlayan nitel araştırma yöntemi kullanılmış, verilerin çözümlenmesinde ise "içerik analizi" tekniğinden yararlanılmıştır.

Görüşme formlarının uygulanması aşaması bizzat araştırmacı tarafindan yapılmış ve yeri geldiğinde araştırmacı gerekli açıklamalarda bulunulmuş ve elde edilen veriler yorumlanmıştır. Araştırma uygulandıktan sonra verilerin çözümlenmesinde içerik analizi kullanılmıştır. Büyüköztürk, Akgün, Çakmak, Demirel ve Karadeniz (2018) içerik analizi, bireylerin davranışları hakkında dolaylı yollarla çalışmaya fursat sunan tekniktir. Verilerin analizi ve yorumlanması ise Saban (2009) beş aşamadan oluşmaktadır.

1. Kodlama ve ayıklama aşaması; Veriler rakamlarla kodlanmış, metaforun yer aldığı ancak gerekçelendirilmeyen, 75 "Görüşme Formu" anlamsız ifadeler içerdiği için elenmiş ve değerlendirmeye alınmamıştır.

2. Örnek metafor derleme aşaması; Katılımcılar tarafindan üretilen metaforlar kodlamalarla çözümlenmiş, üretilen metaforlarda benzeyenler arasında ilişki kurularak ele alınmıştır.

3. Kategori oluşturma aşaması; Çalışkanlık değerine bağlı olarak üretilen metaforlar, çünkü "........." da yer alan gerekçelerine göre kategorilere ayrılmıştır.

4. Geçerlik ve güvenirlik aşaması; Araştırmaya toplam 207 öğrenci katılmış, elde edilen kavramlardan üst tema olarak kategoriler ve alt başlıklarda ise metaforların, kavramsal kategorileri temsil edebilirliğinin yaklaşık $1 / 3$ oranında olduğu tespit edilmiştir. $\mathrm{Bu}$ bağlamda 75 öğrencinin "çalışkanlık” değeri ile ilgili “çünkü” kısmından sonra verdiği cevaplarda içerik olarak bir anlam oluşmadığ 1 için araştırma kapsamından çıkarılmıştır.

5. Elde edilen verilerin bilgisayara aktarılması; gerekçelerine göre kategorilere ayrılan metaforlar, temsil ettiği kategoride yer alan katılımcıların sayısı frekansı (f) hesaplanmıştır. Gerekçelerine göre kategorilere ayrılan metaforlar katılımcılara göre kodlanarak raporlaştırılması yapılmıştır.

Geçerlilik ve güvenirlilik, yapılan araştırmalarda elde edilen sonuçların inandırıcı olmasını sağlamak ve inandırıcılığını artırmak amacı ile araştırmalarda kullanılan en önemli iki ölçüttür (Yıldırım ve Şimşek, 2006). Araştırmanın geçerliliğini sağlamada iki temel sürece dikkat edilmiştir. 
(1) Verilerin analizi sürecinin detaylı olarak açıklanması, (2) Elde edilen bulguların işlenme ve yorumlanması çalışmalarında bizzat öğrencilerin kendileri tarafından yazdıkları metafor cümleleri veri kaynağına temel oluşturmuş, bazı öğrencilerin metafor cümleleri de doğrudan alıntı yapılarak yazılmıştır. Araştırmada iç güvenirliliği sağlamak amacıyla iki araştırmacı araştırmanın tüm süreçlerinde birlikte çalışmış; araştırmanın problem cümlesinin yazılması, araştırma desenin oluşturulması, çalışkanlık değeri metaforun belirlenmesi, verilerin toplanması ve elde edilen verilerin yorumlanması süreçlerinde uyum içinde çalışılmıştır.

Araştırmada ye alan tüm karşılaştırmalarda araştırmacıların görüş birliğini sağlayan ve görüş ayrılığını ortaya koyan ve araştırmada iç güvenilirliği sağlamak için Miles ve Huberman (1994) tarafından ortaya konulan (Güvenirlik = Görüş Birliği / Görüş Birliği + Görüş Ayrıllğı) formülü ile gerekli hesaplanmalar yapılmıştır. Netice olarak yapılan araştırmada yapılan değerlendirmeler arasında uyumun \% 90 civarında olması beklenen bir güvenilirliğin gerçekleşmiş olduğunu gösterir. Araştırmada yapılan güvenirlik çalışmasında elde edilen verilere göre 5. sınıf öğrenci metaforları için $\%$ 89; 6. sınıf öğrenci metaforları için \% 84; 7. sınıf öğrenci metaforları için \% 90 ve 8. sınıf öğrenci metaforları için \% 92 olacak şekilde güvenirlik sağlandığı görülmüştür.

Araştırmanın, görüşme formu oluşturulduktan sonra uzman görüşü alınarak uygulanmıştır. Elde edilen veriler gözden geçirilmiş, anlam bütünlügüne göre dört ana kategoriye ayrılmıştır. Kategorilerin oluşturulması tamamlandıktan sonra uzman görüşüne başvurulmuştur. Araştırmada, ortaokul öğrencilerinin "Çalışkanlık" kavramına ilişkin sınıf düzeyleri ve cinsiyetlerine göre metaforik algıları hakkında elde edilen bulgular yorumlanarak sonuçları yazılmış ve bu sonuçlara bağlı olarak öneriler geliştirilmiştir. Araştırmanın tamamı hakkında iki uzman görüşü alınmış ve intihal kontrolü yapılmıştır.

\section{Bulgular}

Çalışkanlık değerine yönelik elde edilen veriler farklı anlamda kullanılanlar olmak üzere dört kategoride ele alınmıştır. Veriler görüşmeye katılanların sınıf ve cinsiyet durumlarına göre yorumlanmıştır. Çalışkanlık değerine yönelik oluşan kategoriler; "Mücadele, beklenti, sorumluluk, planlı olma ve düzen" kategorileridir. Bu bağlamda ilk olarak "Mücadele” kategorisindeki metaforlar sınıf ve cinsiyet değişkenine göre Tablo 1'de verilmiştir:

Tablo 1

Çalışkanlık Değerine İlişkin 'Mücadele”' Kategorisindeki Metaforlar

\begin{tabular}{|c|c|c|c|c|c|c|c|c|c|c|c|c|}
\hline \multicolumn{13}{|c|}{ Sinıf Düzeyi } \\
\hline \multirow[b]{2}{*}{ S.N. } & \multirow[b]{2}{*}{ Metafor } & \multicolumn{2}{|c|}{ 5. Sinif } & \multicolumn{2}{|c|}{ 6. Sinif } & \multicolumn{2}{|c|}{ 7. Sinif } & \multicolumn{2}{|c|}{ 8. Sinif } & \multicolumn{3}{|c|}{ Cinsiyet } \\
\hline & & $\mathrm{E}$ & $\mathrm{K}$ & $\mathrm{E}$ & $\mathrm{K}$ & $\mathrm{E}$ & $\mathrm{K}$ & $\mathrm{E}$ & $\mathrm{K}$ & $\mathrm{E}$ & $\mathrm{K}$ & (f) \\
\hline 1 & Karınca & 7 & 4 & 3 & 2 & 5 & 2 & 2 & 1 & 17 & 9 & 26 \\
\hline 2 & Ar1 & 0 & 1 & 2 & 5 & 1 & 3 & 0 & 1 & 3 & 10 & 13 \\
\hline 3 & Azim & 0 & 0 & 0 & 0 & 1 & 1 & 4 & 2 & 5 & 3 & 8 \\
\hline 4 & Başarı & 0 & 0 & 0 & 0 & 1 & 0 & 1 & 1 & 2 & 1 & 3 \\
\hline 5 & Güneş & 0 & 2 & 0 & 0 & 0 & 0 & 0 & 0 & 0 & 2 & 2 \\
\hline 6 & Emek & 0 & 0 & 0 & 1 & 0 & 0 & 0 & 1 & 0 & 2 & 2 \\
\hline 7 & A ğaç & 0 & 0 & 1 & 0 & 1 & 0 & 0 & 0 & 2 & 0 & 2 \\
\hline 8 & $\begin{array}{l}\text { Doğru Soruya Doğru } \\
\text { Yanıt Vermek }\end{array}$ & 0 & 1 & 0 & 0 & 0 & 0 & 0 & 0 & 0 & 1 & 1 \\
\hline 9 & Gökyüzündeki Yıldız & 0 & 1 & 0 & 0 & 0 & 0 & 0 & 0 & 0 & 1 & 1 \\
\hline 10 & Dünya & 0 & 1 & 0 & 0 & 0 & 0 & 0 & 0 & 0 & 1 & 1 \\
\hline 12 & Bina & 0 & 0 & 0 & 1 & 0 & 0 & 0 & 0 & 0 & 1 & 1 \\
\hline 13 & Tamirci & 0 & 0 & 1 & 0 & 0 & 0 & 0 & 0 & 1 & 0 & 1 \\
\hline
\end{tabular}




\begin{tabular}{|c|c|c|c|c|c|c|c|c|c|c|c|c|}
\hline 14 & Mücadele & 0 & 0 & 0 & 0 & 0 & 1 & 0 & 0 & 0 & 1 & 1 \\
\hline 15 & Disiplinli Olmak & 0 & 0 & 0 & 0 & 0 & 1 & 0 & 0 & 0 & 1 & 1 \\
\hline 16 & $\begin{array}{l}\text { Sorumluluk Sahibi } \\
\text { İnsan Olmak } \\
\text { İnsanın İcinde }\end{array}$ & 0 & 0 & 0 & 0 & 1 & 0 & 0 & 0 & 1 & 0 & 1 \\
\hline 17 & Bulunan Bir Organ & 0 & 0 & 0 & 0 & 0 & 0 & 0 & 1 & 0 & 1 & 1 \\
\hline 18 & $\begin{array}{l}\text { Zor Bir Matematik } \\
\text { Sorusu }\end{array}$ & 0 & 0 & 0 & 0 & 0 & 0 & 0 & 1 & 0 & 1 & 1 \\
\hline 19 & Hak Etmek & 0 & 0 & 0 & 0 & 0 & 0 & 0 & 1 & 0 & 1 & 1 \\
\hline 20 & Atatürk & 0 & 0 & 0 & 0 & 0 & 0 & 0 & 1 & 0 & 1 & 1 \\
\hline 21 & Kelebeğin Ömrü & 0 & 0 & 0 & 0 & 0 & 0 & 0 & 1 & 0 & 1 & 1 \\
\hline 22 & Miknatıs & 0 & 0 & 0 & 0 & 0 & 0 & 0 & 1 & 0 & 1 & 1 \\
\hline 23 & Kalem & 0 & 0 & 0 & 0 & 0 & 0 & 0 & 1 & 0 & 1 & 1 \\
\hline 24 & İnşaat İşçisi & 0 & 0 & 0 & 0 & 0 & 0 & 0 & 1 & 0 & 1 & 1 \\
\hline 25 & Yüzücü & 0 & 0 & 0 & 0 & 0 & 0 & 1 & 0 & 1 & 0 & 1 \\
\hline 26 & Alabora Olmak & 0 & 0 & 0 & 0 & 0 & 0 & 1 & 0 & 1 & 0 & 1 \\
\hline 27 & Hayat & 0 & 0 & 0 & 0 & 0 & 0 & 1 & 0 & 1 & 0 & 1 \\
\hline 28 & Saat & 0 & 0 & 0 & 0 & 0 & 0 & 1 & 0 & 1 & 0 & 1 \\
\hline 29 & Makine & 1 & 0 & 0 & 0 & 0 & 0 & 0 & 0 & 1 & 0 & 1 \\
\hline & Toplam (f) : 29 & 8 & 10 & 7 & 9 & 10 & 8 & 12 & 15 & 37 & 42 & 79 \\
\hline
\end{tabular}

Yukarıda yer alan Tablo 1'e göre, "Mücadele” kategorisinde toplam 29 metaforun yer aldığ1 ve 79 katılımcının görüş bildirdiği görülmektedir. Bu kategoride bulunan metaforların frekans dağılımları incelendiğinde öğrencilerin karınca, arı, azim metaforlarına yoğunlaştıkları, diğer metaforların ise genellikle katılımcılar tarafindan tek görüşle temsil edildiği görülmektedir. Cinsiyet açısından ortaokul beşinci sınıf erkek öğrencilerin karınca metaforunda, altıncı sınıf kız öğrencilerin ise arı metaforunda yoğunlaştıkları görülmektedir. Kız öğrenciler erkek öğrencilerden farklı olarak; doğru soruya doğru yanıt verme, gökyüzündeki yıldız, dünya, güneş, bina emek, mücadele, disiplinli olma, organ, zor matematik sorusu, hak etme, Atatürk, kelebeğin ömrü, mıknatıs, kalem, inşaat işçisi metaforlarını kullanmışlardır. Erkek öğrenciler ise kız öğrencilerden farklı olarak; tamirci, sorumluluk sahibi insan olma, ağaç, yüzücü, alabora, hayat, saat, makine metaforlarını kullanmışlardır. Tüm katılımcı öğrencilerden sekizinci sınıfların mücadele kategorisinde daha çok metafor oluşturduklarını söyleyebiliriz. Oluşturulan metaforlar dağılımlarını kız ve erkek açısından incelediğimizde birbirine yakın sayıda görüş bildirdikleri söylenebilir. Sınıf düzeyi açısından bakıldığında "Mücadele" kategorisinde 5. sinıf düzeyinde 18 metafor, 6. sınıf düzeyinde 16 metafor, 7. sinıf düzeyinde 18 metafor ve en çok 8. sınıf düzeyinde ise 27 metafor üretilmiştir. Aşağıda "Çalışkanlık" değerine yönelik "Mücadele" kategorisinde yer alan metaforlara ait katılımcı görüşlerine doğrudan yer verilmiştir:

Ö5) Çalı̧̧kanlık, Karıncaya benzer. Çünkü, karıncalar hiçbir zaman pes etmezler. Kendilerine güvenirler, hiç yorulmazlar.

Ö39) Çallşkanlık, Karıncaya benzer. Çünkü, bir karınca yazları yiyecek toplar, çalışır, yuva yapar ve klşın keyfini çıkarır karınca ve ă̆ustos böceğinin bir hikayesi vardır. Ăgustos böceği yazları yatar klşlar donar ama karınca keyfini çıkarır.

Ö23) Çalışkanlı, Arıya benzer. Çünkü, arılar hep çalışır. Hep bal yapar. Bizde öyle öyle çalışıyoruz. Arılar nasıl çiçeklerden polen toplayıp çalışıyorlarsa bizde öyle çalışıyoruz.

Ö25) Çalışkanlık, Binaya benzer. Çünkü, sağlam bir temel atarsan ve sürekli üzerine bir şeyler koyarsan çalışkanlık zaten kendi kendine olur. Ama sağlam bir temel yoksa bir ay bir demir, bir sonraki ay bir taş koymaya kalkarsan o bina hiç bitmez ve büyüme, çalışkan olamazsın.

Ö32) Çalışkanlık, Karıncaya benzer. Çünkü, karıncalar gece gündüz çalışır. Yani yazın çok çalışır, bizim sınav haftamız gibi, kışın rahatına bakar. Yani bizim sinavlardan yüksek alıp takdir almamız gibi. Karıncalar tam çalışkanlığa örnektir. 
Ö38) Çalışkanlık, Karıncaya benzer. Çünkü, karıncalar hiç boş vakit geçirmezler, kraliçesi için çalışırlar. Hiç yorulmazlar, yere düşse ayağa kalkar, düşman gelince saklanır, zeki hareketler yaparlar.

Ö9) Çalışkanlık, Insanın İçinde Bulunan Bir Organa benzer. Çünkü, çalışmak hayatımız boyunca devam etmemiz gereken, hayatımızın her aşamasında kullanacağımız bir olay. Her insan zeki olmayabilir ama çalışkan olabilir. Çünkü ne gevşek ne de çok zorlayıcı sadece çaba gerekli.

Ö22) Çalışkanlık, Kelebeğin Ömrüne benzer. Çünkü, çalışmayı bırakırsan başarın uzun sürmez. Çalışkanlık başarı demektir. Çalışırsan başarılı olursun. Çalışkanlık sorumluluk gerektirir. Sorumluluk ise geçmişini bilen geleceğini gören insanlardadır.

Ö31) Çalışkanlık Gayrete benzer. Çünkü, meslek sahibi olmak için çok fazla çalışırsın. Gayret edersin ve en sonunda mutluluğa kavuşursun. Hayatın boyunca mutlu olursun.

Ö45) Çalışkanlık, Emek Harcamaya benzer. Çünkü, çalı̧̧an kişi emek harcayıp kariyer sahibi olmayı amaçlar. Kariyer sahibi olmak için çalışmak gerekir. Onun için çok çalışmaltyız.

Ö21) Çalışkanlık, Azime benzer. Çünkü, bazı şeyler için azim göstermek gerekir. Bir hedefin olması gerekir. Hedefimizin büyük veya küçük olması önemli değildir.

Çalışkanlık değerine ilişkin mücadele kategorisinde ortaokul öğrenciler tarafindan oluşturulan metaforların gerekçelerine bakıldığında; çalışkanlığın mücadele ile ilişkilendirildiği, mücadele eden kişilerin bıkmadan usanmadan çalıştığı, kendi işini kendisinin yaptığı, mücadele ettiğin kadar başarılı olunduğu, güvenilir olduğu, geleceğe hazırlanmak olduğu, sürekli yeni şeyler düşünmek olduğu, gayret gerektirdiği, sabırlı ve azimli olmak gerektiği, hakkıyla çalışma ve emek gerektirdiği, iyi bir eğitim gerektirdiği, kariyer planlamasını önceden yapmak gerektiği gibi düşüncelere dayandığ görülmektedir.

Çalışkanlık değerine yönelik oluşan ikinci kategori ise, "Beklenti" kategorisindeki metaforlar sınıf ve cinsiyet değişkenine göre Tablo 2'de verilmiştir:

Tablo 2

Çalışkanlık Değerine İlişkin 'Beklenti'” Kategorisindeki Metaforlar

\begin{tabular}{|c|c|c|c|c|c|c|c|c|c|c|c|c|}
\hline \multirow[b]{3}{*}{ S.N. } & \multicolumn{12}{|c|}{ Sınıf Düzeyi } \\
\hline & & \multicolumn{2}{|c|}{ 5. Sinif } & \multicolumn{2}{|c|}{ 6. Sinif } & \multicolumn{2}{|c|}{ 7. Sinıf } & \multicolumn{2}{|c|}{ 8. Sinif } & \multicolumn{3}{|c|}{ Cinsiyet } \\
\hline & Metafor & $\mathrm{E}$ & $\mathrm{K}$ & $\mathrm{E}$ & $\mathrm{K}$ & E & $\mathrm{K}$ & $\mathrm{E}$ & $\mathrm{K}$ & $\mathrm{E}$ & $\mathrm{K}$ & (f) \\
\hline 1 & Kitap & 0 & 0 & 0 & 3 & 0 & 0 & 0 & 0 & 0 & 3 & 3 \\
\hline 2 & Yetenek & 1 & 0 & 0 & 0 & 0 & 1 & 0 & 1 & 1 & 2 & 3 \\
\hline 3 & A ğaç & 0 & 0 & 1 & 0 & 0 & 0 & 0 & 1 & 1 & 1 & 2 \\
\hline 4 & Ak1llı Olmak & 0 & 0 & 0 & 0 & 0 & 0 & 2 & 0 & 2 & 0 & 2 \\
\hline 5 & $\begin{array}{l}\text { Sana Verilen Emeği } \\
\text { Kendi Lehine Kullanmak }\end{array}$ & 0 & 0 & 0 & 1 & 0 & 0 & 0 & 0 & 0 & 1 & 1 \\
\hline 6 & Öğrenci & 0 & 0 & 0 & 1 & 0 & 0 & 0 & 0 & 0 & 1 & 1 \\
\hline 7 & Baraj & 0 & 0 & 1 & 0 & 0 & 0 & 0 & 0 & 1 & 0 & 1 \\
\hline 8 & Hesap Makinesi & 0 & 0 & 1 & 0 & 0 & 0 & 0 & 0 & 1 & 0 & 1 \\
\hline 9 & Gelecek & 0 & 0 & 0 & 0 & 0 & 1 & 0 & 0 & 0 & 1 & 1 \\
\hline 10 & Devrim & 0 & 0 & 0 & 0 & 0 & 1 & 0 & 0 & 0 & 1 & 1 \\
\hline 11 & $\begin{array}{l}\text { Binanın Temelini } \\
\text { Oluşturmak }\end{array}$ & 0 & 0 & 0 & 0 & 0 & 1 & 0 & 0 & 0 & 1 & 1 \\
\hline 12 & $\begin{array}{l}\text { Üşenmeden Görevleri } \\
\text { Yerine Getirmek }\end{array}$ & 0 & 0 & 0 & 0 & 0 & 1 & 0 & 0 & 0 & 1 & 1 \\
\hline 13 & Matematik & 0 & 0 & 0 & 0 & 1 & 0 & 0 & 0 & 1 & 0 & 1 \\
\hline 14 & Atom Bombası & 0 & 0 & 0 & 0 & 1 & 0 & 0 & 0 & 1 & 0 & 1 \\
\hline 15 & İnsanın Büyümesi & 0 & 0 & 0 & 0 & 1 & 0 & 0 & 0 & 1 & 0 & 1 \\
\hline 16 & Zengin Olmak & 0 & 0 & 0 & 0 & 1 & 0 & 0 & 0 & 1 & 0 & 1 \\
\hline 17 & $\begin{array}{l}\text { Cenneti Bildiğin İçin } \\
\text { Çabalayıp Sevap İşlemek }\end{array}$ & 0 & 0 & 0 & 0 & 0 & 0 & 0 & 1 & 0 & 1 & 1 \\
\hline 18 & Hazine & 0 & 0 & 0 & 0 & 0 & 0 & 0 & 1 & 0 & 1 & 1 \\
\hline 19 & Balık & 0 & 0 & 0 & 0 & 0 & 0 & 0 & 1 & 0 & 1 & 1 \\
\hline 20 & $\mathrm{Su}$ & 0 & 0 & 0 & 0 & 0 & 0 & 1 & 0 & 1 & 0 & 1 \\
\hline & Toplam (f) : 20 & 1 & 0 & 3 & 5 & 4 & 5 & 3 & 5 & 11 & 15 & 26 \\
\hline
\end{tabular}


Yukarıda yer alan Tablo 2'ye göre, "Beklenti” kategorisinde toplam 20 metaforun yer aldığ 1 ve toplam 26 katılımcının görüş bildirdiği görülmektedir. Bu kategoride bulunan metaforların frekans dağılımları incelendiğinde birkaç metafor hariç genel olarak her metaforun bir katılımcı tarafindan ifade edildiği görülmektedir. Beklenti kategorisinde beşinci sınıflardan sadece bir öğrencinin metafor oluşturduğu, altı, yedi ve sekizinci sınıfların ise hemen hemen birbirlerine yakın sayıda metafor oluşturdukları görülmektedir. Sınıf düzeyi açısından bakıldığında "Beklenti" kategorisinde 5. sınıf düzeyinde 1 metafor, 6. sinıf düzeyinde 8 metafor, 7. sinıf düzeyinde 9 metafor ve 8 . sinıf düzeyinde ise 8 metafor üretilmiştir. Somut işlem döneminde yer alan beşinci sınıf öğrencilerinin bir tane beklenti içeren metafor ürettikleri görülmektedir. Elde edilen verilerin Bloom'un taksonominde yer alan Somut İşlem Dönemi ve Soyut İşlem Dönemi yaklaşımı ile ötüştüğü söylenebilir. Tablo incelendiğinde soyut işlemler dönemi'ndeki öğrencilerin "Beklenti" düzeyinde daha çok metaforlar oluşturdukları görülmektedir. Ayrıca cinsiyet açısından beklenti kategorisinde "çalışkanlık" ile ilgili kı öğrencilerin erkek öğrencilerden daha çok metafor oluşturdukları frekans dağılımından söylenebilir. Kız öğrenciler erkek öğrencilerden farklı olarak; kitap, emek, öğrenci, gelecek, devrim, yetenek, bina temeli, görev ifası, sevap, hazine ve balık metaforlarını kullanmışlardır. Erkek öğrenciler ise kız öğrencilerden farklı olarak; baraj, hesap makinesi, matematik, atom bombası, insanın büyümesi, zengin olma, su, akıllı olmak metaforlarını kullanışlardır. Aşağıda katılımcıların "çalışkanlık" değerine yönelik "Beklenti" kategorisinde yer alan metafor görüşlerine doğrudan yer verilmiştir:

Ö21) Çalışkanlık, Kitaba benzer. Çünkü, bir kitabı okurken sayfalara hiç bakmadan geçersek, o kitabın sonunun ne olduğunu okusak bile tat alamayız. Çalışkanlık da bunun gibi hiç çalışmazsak sonumuzu hayal edemeyiz. Çalışkanlık, hayal edebildiğimiz ve yaşarken tat alacağımız bir son.

Ö44) Çalışkanlık, Zeki Olmaya benzer. Çünkü, zeki olursak ve daha başarllı olursak çalışkanlığımızın kanıtı olur. Bizim görevimiz okuyup başarılı olmamızdır. Bizim bu görevleri yerine getirmemiz lazım.

Ö6) Çalışkanlık, Ağaç Sulamaya benzer. Çünkü, çiçeği sularsan çiçek büyür, çalıştıkça da başarılı olursun. Ĕger çiçeğin suyunu vermezsen yani çalışmasan çiçek büyümez yani başarılı olamazsin.

Ö20) Çalışkanlık, Hesap Makinesine benzer. Çünkü, hesap makinesi bütün matematik işlemlerini yapabilecek güçtedir.

Ö31) Çalışkanlık, Binanın Temelini Oluşturmaya benzer. Çünkü, çalışmadan bir işe kalkışmak, tıp okumadan doktor olmak gibidir. Yani işin temelini kurmazsan genellikle başarılı olamayız.

Ö14) Çalışkanlık, Atom Bombasına benzer. Çünkü, bir yıl boyunca çalışırsan notların yüksek şekilde patlar. $O$ notlar patlayınca ailenden yüksek değerli eşyalar, oyuncaklar, elektronik aletler ve daha birçok ödül kazanirsin.

Ö8) Çalışkanlık, Cenneti Bildiğin İçin Çabalayıp Sevap İşlemeye benzer. Çünkü, çalıştı̆̆ımız zaman ileride bunların pozitif yönlerini göreceğizdir. Cennet gibi bir yaşam vaad ediliyor ve bunun için çalışıyoruz. Kendimiz için çalışmamızın karşıllı̆̆ını ziyadesiyle alacağız. Tıpkı sevaplarımızla cennete girdiğimiz gibi, çözdüğ̈̈müz sorularla da hayalini kurduğumuz mesleğe sahip oluruz.

Ö30) Çalışkanlık, Hazineye benzer. Çünkü, altın hazineyi doğru kullanan geleceğini de güzel hazırlar, doğru yerlerde kullanırsak ĕger her zaman değerlenir.

Ö5) Çallşkanlık, Suya benzer. Çünkü, bir bitkiyi ne kadar sularsan o solmaz büyür.

Çalışkanlık değerine ilişkin "Beklenti" kategorisinde ortaokul öğrenciler tarafından oluşturulan metaforların gerekçelerine bakıldığında; çalışkanlığın beklenti ile ilişkilendirildiği, beklentinin ülke için bir şey yapmak olduğu, kendini yetiştirmek olduğu, bir şeyler üretir hale gelmek olduğu, kendisine vatanına çevresine hayırlı biri olmak olduğu, görev bilincinin gelişmesini içerdiği, meslek sahibi olmak olduğu, kendini yenilemek olduğu, hem bu dünya için hem de ahiretteki yaşam için hazırlanmak olduğu, sabırlı olunması gerektiği gibi düşüncelere dayandığı görülmektedir.

Çalışkanlık değerine yönelik oluşan 3. kategori ise, "Sorumluluk" kategorisindeki metaforlar sınıf ve cinsiyet değişkenine göre Tablo 3'te verilmiştir: 
Tablo 3

Çalışkanlık Değerine İlişkin “Sorumluluk” Kategorisindeki Metaforlar

\begin{tabular}{|c|c|c|c|c|c|c|c|c|c|c|c|c|}
\hline \multicolumn{13}{|c|}{ Sınıf Düzeyi } \\
\hline \multirow[b]{2}{*}{ S.N. } & \multirow[b]{2}{*}{ Metafor } & \multicolumn{2}{|c|}{ 5. Sinıf } & \multicolumn{2}{|c|}{ 6. Sinif } & \multicolumn{2}{|c|}{ 7. Sinif } & \multicolumn{2}{|c|}{ 8. Sinif } & \multicolumn{3}{|c|}{ Cinsiyet } \\
\hline & & E & $\mathrm{K}$ & E & $\mathrm{K}$ & E & $\mathrm{K}$ & E & $\mathrm{K}$ & E & $\mathrm{K}$ & (f) \\
\hline 1 & Anne ve & 2 & 1 & 0 & 0 & 0 & 0 & 0 & 0 & 2 & 1 & 3 \\
\hline 2 & Kitap & 2 & 0 & 0 & 0 & 0 & 0 & 0 & 0 & 2 & 0 & 2 \\
\hline 3 & Ar1 & 1 & 1 & 0 & 0 & 0 & 0 & 0 & 0 & 1 & 1 & 2 \\
\hline 4 & Başarı & 1 & 1 & 0 & 0 & 0 & 0 & 0 & 0 & 1 & 1 & 2 \\
\hline 5 & $\begin{array}{l}\text { Bağımsız Bir } \\
\text { Ülke }\end{array}$ & 0 & 1 & 0 & 0 & 0 & 0 & 0 & 0 & 0 & 1 & 1 \\
\hline 6 & Matematik & 0 & 1 & 0 & 0 & 0 & 0 & 0 & 0 & 0 & 1 & 1 \\
\hline 7 & Anlamak & 1 & 0 & 0 & 0 & 0 & 0 & 0 & 0 & 1 & 0 & 1 \\
\hline 8 & Karınca & 0 & 1 & 0 & 0 & 0 & 0 & 0 & 0 & 0 & 1 & 1 \\
\hline 9 & Çiçek & 1 & 0 & 0 & 0 & 0 & 0 & 0 & 0 & 1 & 0 & 1 \\
\hline 10 & $\begin{array}{l}\text { Ak1lli } \\
\text { Telefon }\end{array}$ & 1 & 0 & 0 & 0 & 0 & 0 & 0 & 0 & 1 & 0 & 1 \\
\hline To & $\operatorname{lam}(f): 10$ & 9 & 6 & 0 & 0 & 0 & 0 & 0 & 0 & & & \\
\hline
\end{tabular}

Yukarıda yer alan Tablo 3'e bakıldığında, "Sorumluluk" kategorisinin toplam 10 metafor ve 15 katılımcının görüşleri yer almaktadır. Bu kategoride bulunan metaforların frekans dağılımları incelendiğinde birkaç metafor hariç genel olarak her metaforu bir katılımcının ifade ettiği görülmektedir. Sınıf düzeyi açısından bakıldığında "Sorumluluk" kategorisinde 5. sınıf düzeyinde 15 metafor, 6. 7. 8. sınıf düzeyinde ise hiç metafor üretmedikleri görülmektedir. Bu durum çalışmaya katılan öğrencilerin somut işlem dönemi'nde olduklarından sorumluluk kategorisinde beşinci sınıf düzeyinde sorumluluk duygusunun daha güçlü olduğu bilgisi ile örtüştüğü söylenebilir. Katılımcılardan çalışkanlık değeri ile ilgili sorumluluk kategorisinde anne, başarı, kitap ve arı metaforlarının ağırlıklı olarak ön plana çıktığı söylenebilir. Bu kategoride cinsiyet açısından kız ve erkek öğrencilerin birbirine yakın düzeyde görüş belirttikleri görülmektedir. Kız öğrenciler erkek öğrencilerden farklı olarak karınca, bağımsız ülke, matematik metaforları yapmışlardır. Erkek öğrenciler ise kız öğrencilerden farklı olarak anlama, kitap, çiçek, akı1lı telefon metaforları yapmışlardır. Aşă̆ıda katılımcıların "Çalışkanlık" değerine yönelik "Sorumluluk" kategorisinde yer alan metaforlara ait katılımcı görüşlerine doğrudan yer verilmiştir:

Ö19) Çalışkanlık, Başarıya benzer. Çünkü, bir insan başarılıysa 85 ve üstü alır, çalışkandır. Tembelsek çok kötü notlar alırız. 25-29-32 vb. başarılı olunca takdir alırız. Insan çok çalışınca güzel olur. Bir insan başarllıysa takdir alır, başarısızsa boş geçer orta ya da teşekkür alır. Başarılı olup olmadı̆̆ın bellidir.

Ö13) Çalışkanlık, Anneye benzer. Çünkü, annem bulaşık yıkıyor, yemek yapıyor yani aklına ne geliyorsa yapıyor.

Ö31) Çalışkanlık, Kitaba benzer. Her kitap bize bir şey anlatır ve öğretir.

Çalışkanlık değerine ilişkin "Sorumluluk" kategorisinde ortaokul öğrenciler tarafından oluşturulan metaforların gerekçelerine bakıldığında; çalışkanlığın sorumluluk ile ilişkilendirildiği, sorumlu kişilerin bilgili, sorumlu, akılll, değer verme gibi düşüncelere dayandığı görülmektedir. Sorumluluğun kişiyi olgunlaştıracağı, hoşgörülü yapacağı da ayrıca vurgulanmıştır.

Çalışkanlık değerine yönelik oluşan 4. kategori ise, "Planlı olma ve Düzen" kategorisindeki metaforlar Tablo 4'te sınıf ve cinsiyet değişkenine göre verilmiştir: 
Tablo 4

Çalışkanlık Değerine İlişkin “Planlı Olma ve Düzen” Kategorisindeki Metaforlar

\begin{tabular}{clccccccccccc}
\hline & \multicolumn{10}{c}{ Sınıf Düzeyi } \\
\hline & & 5. Sinıf & \multicolumn{1}{c}{ 6. Sinıf } & \multicolumn{1}{c}{ 7. Sinıf } & \multicolumn{1}{c}{ 8. Sinıf } & \multicolumn{3}{c}{ Cinsiyet } \\
S.N. & \multicolumn{1}{c}{ Metafor } & E & K & E & K & E & K & E & K & E & K & (f) \\
\hline 1 & Satranç & 0 & 1 & 1 & 1 & 0 & 0 & 1 & 0 & 2 & 2 & 4 \\
& Güneş Sistemindeki & & & & & & & & & & & \\
2 & Düzen & 2 & 0 & 0 & 0 & 0 & 0 & 0 & 0 & 2 & 0 & 2 \\
3 & Karınca & 1 & 0 & 1 & 0 & 0 & 0 & 0 & 0 & 2 & 0 & 2 \\
4 & Dürüst Olmak & 0 & 0 & 0 & 0 & 0 & 1 & 1 & 0 & 0 & 2 & 2 \\
5 & Arı & 0 & 0 & 1 & 0 & 1 & 0 & 0 & 0 & 2 & 0 & 2 \\
6 & Rüzgârgülü & 0 & 0 & 0 & 0 & 0 & 1 & 0 & 0 & 1 & 0 & 1 \\
7 & Futbol Oynamak & 1 & 0 & 0 & 0 & 0 & 0 & 0 & 0 & 1 & 0 & 1 \\
8 & Planlı ve Düzenli Olmak & 0 & 0 & 0 & 0 & 0 & 0 & 0 & 1 & 0 & 1 & 1 \\
9 & Hayat & 0 & 0 & 1 & 0 & 0 & 0 & 0 & 0 & 1 & 0 & 1 \\
\hline & Toplam (f) : 9 & 4 & 1 & 4 & 1 & 1 & 2 & 2 & 1 & 11 & 5 & 16 \\
\hline
\end{tabular}

Tablo 4'e bakıldığında, "Planlı Olma ve Düzen" kategorisinde sınıf düzeyi açısından bakıldığında "Planlı Olma ve Düzen" kategorisinde 5.sınıf düzeyinde 5 metafor, 6.sınıf düzeyinde 5 metafor, 7. sınıf düzeyinde 3 metafor ve 8 . sınıf düzeyinde ise 3 metafor üretilmiştir. "Planlı olma ve Düzen" kategorisinide tüm sınıfların birbirine yakın sayıda metafor ürettikleri söylenebilir. Cinsiyet açısıdan erkek öğrencilerin kız öğrencilerden daha çok metafor üretmişlerdir. Kız öğrenciler erkek öğrencilerden farklı olarak; rüzgar gülü, dürüst olma, planlı ve düzenli olma metaforlarını kullanmışlardır. Erkek öğrenciler ise kız öğrencilerden farklı olarak; güneş sistemindeki düzen, futbol oynama, karınca, arı, hayat metaforlarını kullanmışlardır. "Çalışkanlık" değerine yönelik "Planlı Olma ve Düzen" kategorisinde 9 katılımcının 16 metafor ürettiği görülmektedir. Aşağıda "Planlı olma ve Düzen" kategorisinde yer alan metaforlara ait katılımcı görüşlerine doğrudan yer verilmiştir:

Ö18) Çalışkanlık, Satranca benzer. Çünkü, satrançta hem inanmak hem düşünmek gerekir. Satrançta kuralları bilmek gerekir. Çalışkanlığında kuralları vardır. Bunları bilmek önemlidir.

Ö20) Çalışkanlık, Futbol Oynamaya benzer. Çünkü, futbol takım şeklinde oynanır. Planlı oynanir.

Ö35) Çalışkanlık, Güneşe benzer. Çünkü, çalışkanlık güneş gibi herkese faydalıdır.

Ö39) Çallşkanlı, Dürüst Olmaya benzer. Çünkü, çalışkan bir insan sorumluluklarını, ne yapması gerektiğini bilir. Elinden geleni yapar.

Ö43) Çallşkanlık, Planlı ve Düzenli Olmaya benzer. Çünkü, çalışırken herkes düzenli, planl,, programlı çalışır. Düzenli, planlı, programlı çalışmazsak başarıya ulaşmayız. Planlı hayat daha başarll hayat demektir.

Çalışkanlık değerine ilişkin "Planlı Olma ve Düzen" kategorisinde ortaokul öğrenciler tarafından oluşturulan metaforların gerekçelerine bakıldığında; çalışkanlığın "Planlı Olma ve Düzen" ile ilişkilendirildiği, planlı olan kişilerin kurallı hareket ettiği, düzenli oldukları, takım çalışması yapabilecekleri, uyumlu oldukları, çevrelerinde başarılı olmasından dolayı herkes tarafindan saygı göreceği, sevileceği, planlı kişilerin çevrelerinde başarılı olmalarına vurgu yapıldığı, insanların planlı çalışmalarından dolayı çevrelerinde takdir görüldüğü, onure edildiği, planlı çalışanların gelecekte rahat edebileceği, gibi düşüncelere dayandırdıkları görülmektedir.

\section{Sonuç, Tartışma ve Öneriler}

Araştırmanın sonucuna göre "Çalışkanlık" değerne yönelik katılımcılar taradından 68 metafor geliştirilmiştir. araştırmacılar tarafından geliştirilen metaforlar dört kategoriye ayrılarak değerlendirilmiştir. Araştırmaya katılan öğrencilerin geliştirdikleri metaforlar aracılığ ile kendi içinde kategoriler oluşturulmuştur. 5,6,7 ve 8. Sınıf öğrencilerinin çalışkanlık değerine yönelik algıları incelendiğinde "Mücadele", "Beklenti", "Sorumluluk", "Planlı Olma ve Düzen", kategorilerinden 
oluştuğu görülmektedir. Bu kategorilerden sirasıyle en çok 79 görüşle "Mücadele" ve 26 görüşle "Beklenti" kategorilerinde metaforlara yer verildiği görülmektedir. Daha sonra sirayla 16 görüşle "Planlı Olma ve Düzen" kategorisi ve en az 15 görüşle "Sorumluluk" kategorilerinde metaforlar olmuştur. 5. 6. 7. ve 8. sinıf öğrencilerinde "Çallşkanlık" denildiğinde daha çok "Mücadele ve beklenti" çağrıştırdığg görülmektedir. Araştırmaya katılan beşinci sınıf öğrencilerinin daha çok somut kavramlar (Karınca, arı, dünya, güneş, anne ve baba, kitap, satranç) sekizinci sınıf öğrencilerinin ise daha çok soyut kavramları (azim, başarı, meslek, yetenek, akıllı olmak, dürüst olmak, planlı ve düzenli olmak) kullanmışlardır. Tulunay Ateş (2016) öğrencilerin öğretmen hakkında oluşturdukları "Çalışkan ve mücadeleci biri" kategorisinde belli metaforları (Karınca, arı, dağ) topladıkları görülmektedir. $\mathrm{Bu}$ durum araştırma sonucunda ortaya çıkan "Mücadele" kategorisi ile benzerlik göstermektedir.

Çalışkanlık değerine yönelik 5, 6, 7 ve 8 . sınıf öğrencilerinin verdiği cevaplar kategorilere ayrılarak incelendiğinde toplam 136 metafor yer almaktadır. Öğrencilerin "Mücadele" kategorisinde en çok (Karınca, arı, azim, başarı, emek, güneş, meslek, ağaç) metaforlarına yoğunlaştıkları görülmektedir. Mücadele kategorisinde öğrencilerin dikkat çekici olarak (Tamirci, Atatürk, makine, hak etme) gibi metaforları kullanmışlardır. Öğrenciler "Beklenti" kategorisinde (Kitap, ağaç, yetenek, akıllı olmak) metaforlarını yoğun bir şekilde belirtilirken; dikkat çekici olarak da (Hazine, zengin olma, matematik, atom bombası, baraj, hesap makinesi, öğrenci) metaforlarını kullandıkları görülmektedir. "Sorumluluk" kategorisinde ise (Anne ve baba, başarı, arı, kitap) metaforları ön plana çıkarken, aynı zamanda (Çiçek, akıllı telefon, bağımsız bir ülke) metaforlara da yer verdikleri görülmektedir. Öğrenciler "Planlı Olma ve Düzen" kategorisinde ise (Satranç, karınca, arı) metaforları ön plana çıkarken, diğer yandan (Bilgisayar, futbol oynama, hayat, dürüst olma) metaforlarını ise ilginç dikkat çekici metaforlar olarak kullandıkları söylenebilir. Dirican (2013) 3-6 yaş grubu çocuklar ile Türk yazarlar tarafından yazılmış resimli hikâye kitaplarında temel insani değerlerin neler olduğunu yer verilme oranları üzerinde bir metafor çalışması yapmıştır. Bu metafor çalışmasının sonuçları incelendiğinde 3-6 yaş grubu çocuklar için Türk yazarlar tarafından yazılmış resimli hikaye kitaplarında yer verilen değerden birinin de çalışkanlık değeri olduğu tespit edilmiştir.

Metaforik alg1 olarak öğrencilerin verdiği cevaplar incelendiğinde cinsiyet açısından farklılık görülmemiştir. Hem erkek hemde kızların 68'er metafor görüşü bildirdikleri tespit edilmiştir. Ancak öğrencilerin cinsiyetlerine göre sınıf düzeyleri açısından incelendiğinde 5 ve 6 . sinıflar arasında farklılıklar görülsede 7 ve 8 . sinıflarda bir farklılık görülmemektedir. Kız ve erkek öğrencilerin sınıflara göre oluşturduğu metafor algılarına baktığımızda beşinci sınıfta erkek öğrencilerin daha çok görüş oluşturdukları dikkat çekmektedir. Kız öğrencilerin ise altıncı sınıfta erkek öğrencilerden daha fazla metafor oluşturdukları görülmektedir. Erkek ve kız öğrencilerin yedi ve sekizinci sınıflarda birbirine yakın hatta hemen hemen aynı sayıda metafor oluşturdukları tespit edilmiştir.

Öğrencilerinin çalışkanlık değerine yönelik metaforik algıları sınıf düzeyine göre değişmekte midir? Sınıf düzeyi açısından bakıldığında "Mücadele" kategorisinde en çok 8.sınıf düzeyinde metafor üretilmiştir. "Beklenti" kategorisinde en az 5. sınıf düzeyinde metafor üretilirken 6. 7. 8. sınıf düzeyinde üretilen metafor sayıları birbirine yakındır. Bu durum somut işlem döneminde yer alan beşinci sınıf öğrencilerinin, Bloom'un taksonominde yer alan Somut İslem Dönemi ve Soyut İslem Dönemi yaklaşımı ile ötüştüğü söylenebilir. Sınıf düzeyi açısından bakıldığında "Sorumluluk" kategorisinde en çok 5.sınıf düzeyinde metafor üretilmişken, 6. 7. 8.sınıf düzeyinde ise hiç metafor üretmedikleri tespit edilmiştir. Bu durum çalışmaya katılan öğrencilerin sorumluluk duygusunun 5.sınıf düzeyinde daha güçlü olduğu söylenebilir. "Planlı olma ve Düzen" kategorisinide tüm sinıfların birbirine yakın sayıda metafor ürettikleri söylenebilir. Araştırmaya katılan 5, 6, 7 ve 8 . sınıf öğrencilerinin çalışkanlık değerine yönelik algılarında sınıf düzeyinde farklılıklar olduğu görülmektedir. Beşinci sınıf öğrencilerinin oluşturulan dört kategoride de 6,7 ve 8 . sınıf öğrencilerine göre çok sayıda metafor oluşturmuşlardır. Beşinci sınıf ögrencilerinin metafor oluştururken somut varlıklar (arı, dünya, karınca, anne ve baba, kitap, güneş) kullandıkları, altıncı sınıf öğrencilerinin kısmen somut varlıklar üzerinden metafor oluşturduklarını söyleyebiliriz. Yedinci ve sekizinci sınıf öğrencilerinin dikkat çekici bir şekilde soyut kavramlar kullanarak (azim, dürüst olmak, başarı, yetenek, meslek, akıllı olmak) metafor oluşturdukları görülmektedir. Altı ve yedinci sınıf 
öğrencilerinin oluşturduğu metaforlar hem somut varlıkları hem de soyut kavramları içerecek şekilde kullandıkları söylenebilir. Bu durum gelişim psikoloğu Jean Piaget'nin bilişsel gelişim dönemleri kuramı ile uyuşmakta olup, somut işlemler dönemine olan beş ve altıncı sınıflar daha somut varlıklar ve kavramlar üzerinden metaforlar oluştururken yedinci ve sekizinci sınıfların daha çok soyut varlık ve kavramlar üzerinden metaforlar oluşturduğu görülmüştür.

Deveci ve Selanik (2009) beşinci sınıfa devam eden 21 öğrenci ile yaptıkları çalışmalarında, ilköğretim öğrencilerinin günlük yaşamlarında değerlerin yer alma durumunu tespit etmeyi amaçlamışlardır. Yaptıkları araştırma sürecinde öğrencilerden günlük tutmaları istenmiş, öğrenciler tarafından tutulan günlükler tümevarım analiz yöntemi ile incelenmiş ve yapılan analiz sonucunda diğer değerlerden oluşan temaların yanı sıra çalışkanlık değerinin tema oluşturduğu sonucuna ulaşmışlardır. Adı geçen araştırmacıların ulaştığı bulgulara göre, değerler eğitimi konusunda elde edilen temalara göre (çalışkanlık değeri de dahil) okulda yer alan tüm paydaşların işbirliğine gereksinim olduğu sonucuna ulaşılmıştır. Bunun yanı sıra olmazsa olmaz olarak okul-aile işbirliğine gereksinim olduğu, öğrencilerin sınıf seviyelerine göre programda hedeflenen değerleri kazanabilmeleri maksadıyla değerler eğitimine planlı etkinlikler içinde yer verilmesi gerektiği ifade edilmiştir.

- Ortaokul öğrencilerinin çalışkanlık değerine yönelik çalışmaları davranış haline getirmeleri için değerlerin hangi kazanımlarla ilişkilendirilebileceği ders öğretmenleri tarafından önceden belirlenmeli ve ders akışında "çalışkanlık" değerine yönelik sözlü anlatımların yanı sıra, somut örneklere yer verilmeli, ayrıca kompozisyon tipi yazılı anlatım çalışmaları ile güçlendirmeleri önerilebilir.

- Sadece sosyal bilgiler derslerinde değil diğer derslerde de çalışkanlık değerine vurgu yapılmalı, programların içeriğinde yer alan örtük öğrenme yaklaşımına göre gereken önem gösterilmelidir.

- Değerler eğitimi kapsamında yapılan çalışmalarda drama, resim, şekil, grafik gibi çalışmalar yapılmalı, sınıf ve okul koridorlarında pano çalışmaları ile güçlendirilmesine önem verilebilir.

- Sosyal Bilgiler, Türkçe başta olmak üzere diğer derslerde kazanımlara yönelik hazırlanan metinlerden en az birinin çalışkanlık değerine yönelik metin kullanılarak hazırlanabilir.

- Okul ve sınıf düzeyinde çeşitli faaliyet, ders etkinlikler, laboratuvar çalışmaları, sınavlar gibi yapılan çalışmalarda akranlarından farklı çalışmalar yapan öğrenciler çalışkanlık değeri ile ilişkilendirilerek öğrencileri onure edecek ödüllendirme çalışmaları yapılması önerilebilir.

- Duyuşsal beceriler ile değer eğitiminin iç içe verilmesi için sınıflar arasında veya okul düzeyinde çeşitli sanatsal ve sportif faaliyetler düzenlenerek ödüllendirmeler yapılabilir.

\section{Kaynaklar}

Akar, C., İnel, Y. ve Yalçıntaş, E. (2017). Research of levels of democratic values of classroom teacher candidates on various variables. Journal of current researches on educational studies, 7(2). doi: 10.26579/jocures-7.2.4.

Aktepe, V. (2010). Illköğretim 4. sinıf sosyal bilgiler dersinde "yardımseverlik" değerinin etkinlik temelli ögretimi ve ögrencilerin tutumlarına etkisi. Doktora Tezi, Gazi Üniversitesi, Eğitim Bilimleri Enstitüsü, Ankara.

Aktepe, V. ve Tahiroğlu, M. (2016). Değerler eğitimi yaklaşımları ve etkinlik örnekleri. The Journal of Academic Social Science Studies, 42, 361-384.

Arslan, M. M. ve Bayrakçı, M. (2006). Metaforik düşünme ve öğrenme yaklaşımının eğitim öğretim açısından incelenmesi. Millî Eğitim Dergisi, 171, 100-107. 
Aydın, E ve Sulak, S. (2015). Sınıf öğretmeni adaylarının değer kavramına yönelik metafor algıları. Bartin University Journal of Faculty of Education, 4(2), 482-500. DOI: 10.14686/buefad.v4i2.5000148420

Ayverdi, İ. (2011). Misalli Büyük Türkçe Sözlük. İstanbul: Kubbealtı Yayınevi.

Balc1, A. ve F. Yanpar Yelken, T. (2013). İlköğretim sosyal bilgiler programında yer alan değerler ve değer eğitimi uygulamaları konusunda öğretmen görüşleri. Ahi Evran Üniversitesi Kırşehir Eğitim Fakültesi Dergisi (KEFAD), 14(1), 195-213.

Binbaşıoğlu, C. (1991). Genel öğretim bilgisi, ilk ve orta dereceli okul öğretmenleri için öğretimde ilke, yöntem ve teknikleri (6. Basım). Ankara: Kadıŏlu Yayınevi.

Büyüköztürk, Akgün, Çakmak, Demirel ve Karadeniz. (2018). Bilimsel araştırma yöntemleri (24. Bask1). Ankara: PegemA Yayıncılık.

Cerit, Y. (2008). Öğretmen kavramı ile ilgili metaforlara ilişkin, öğretmen ve yöneticilerin görüşleri. Türk Ë̆itim Bilimleri Dergisi, 6(4), 693-712.

Cora, İ. (1990). Ahilik örgütünün Osmanlı toplumundaki yeri ve ahilik örgütü ilkelerinin günümüz esnaf ve zanaatkârlarına uygulanabilirliği. Yüksek Lisans Tezi, Marmara Üniversitesi, Sosyal Bilimler Enstitüsü, İstanbul.

Çelikkaya, T. ve Seyhan, O. (2017). Sosyal bilgiler öğretmenlerinin ve öğretmen adaylarının evrensel değerlere ilişkin metafor algıları. E-Uluslararası Eğitim Araştırmaları Dergisi, 8(3), 65-87. DOI: 10.19160/ijer.342330.

Demirkaya, H. ve Çal, Ü. T. (2018). Sosyal bilgiler öğretmen adaylarının dürüstlük değerine ilişkin metaforik algıları. Kırşehir Ĕ̈itim Fakültesi Dergisi, 19(3), 1981-1998.

Deveci, H. ve Selanik Ay, T. (2009). İlköğretim öğrencilerinin günlüklerine göre günlük yaşamda değerler. Uluslararası Sosyal Araştırmalar Dergisi, 2(6), 167- 181.

Dirican, R. (2013). 3-6 Yaş grubu çocuklarına yönelik yayımlanan resimli hikâye kitaplarının bazı temel değerler açısından incelenmesi. Yüksek Lisans Tezi, Gazi Üniversitesi, Eğitim Bilimleri Enstitüsü, Ankara.

Erdem, A. R. (2003). Üniversite kültüründe önemli bir unsur: Değerler. Değerler Eğitimi Dergisi, l(4), 55-72.

Er-Türküresin, H., Başer, E ve Yapıcı, H. (2018). Ortaokul öğrencilerinin dayanışma kavramına ilişkin algılarının metaforlar yoluyla incelenmesi. Kuramsal Eğitimbilim Dergisi, UBEK- (2018), 6180 .

Gökyay, O.Ş. (1973). Dedem Korkut’un kitabı. İstanbul: Millî Eğitim Yayınevi.

Gömleksiz, M., Kan, A ve Öner, Ü. (2012). Sosyal bilgiler öğretmen adaylarının bir değer olarak demokrasi kavramına ilişkin metaforik algıları. Değerler Eğitimi Dergisi, 10(24) , 79-100.

Gutek, G. L. (2011). Ĕ̈itimde felsefi ve ideolojik yaklaşımlar (3. Basım) (Çev. N. Kale). Ankara: Ütopya Yayinları.

Gündüz, M., Saygılı, G. ve Sulak, S.E. (2014). Sınıf Öğretmenlerinin 3. sınıf öğrencilerine değerler eğitimiyle kazandırılmak istenen davranışlara yönelik metaforik algıları. Eğitim ve İnsani Bilimler Dergisi, 5(10), 73-94 
Güngör, E. (2000). Değerler psikolojisi üzerine araştırmalar (3. Baskı). İstanbul: Ötüken Yayınları.

Halstead, J. M. and Taylor, M. J. (2000). Learning and teaching about values: A review of recent research. Cambridge Journal Of Education, 30(2). 169-202.

İnel, Y., Urhan, E ve Ünal, A. (2018). Ortaokul öğrencilerinin adalet kavramına ilişkin metaforik alg1lar1. Anadolu Journal Of Educational Sciences International, 8(2) , 379-402.

Karadeniz, O., Er, H. ve Tangülü, Z. (2014). 8. Sınıf öğrencilerinin SBS'ye yönelik metaforik algıları. Uluslararast Avrasya Sosyal Bilimler Dergisi, 5(15), 64-81.

Kunduroğlu, T. (2010). 4. Sinıf fen ve teknoloji dersi ögretim programıyla bütünleştirilmiş "değerler eğitimi” programının etkililiğinin incelenmesi. Yüksek Lisans Tezi, Ankara Üniversitesi, Ankara.

Lacoff, G. and Johnson, M. (2005). Metaforlar, hayat anlam ve dil (Metaphors We Lived By) (Çev. G. Y. Demir). Chicago, IL: The University Of Chicago Press.

Millî Eğitim Bakanlığı. (2018). Millî Ĕgitim Bakanlı̆̆ Sosyal Bilgiler Öğretim Programı. http://mufredat.meb.gov.tr/Dosyalar/201812103847686 internet sayfasından 15 Kasım 2019 tarihinde alınmıştır.

Özden, Y. (2005). Ĕ̆itimde yeni değerler. Ankara: Pegem A Yayıncılık.

Öztürk, C. ve Otluoğlu, R. (2005). Sosyal Bilgiler ögretiminde edebi ürünler ve yazıl materyaller (3. Baskı). Ankara: PegemA Yayıncılık.

Patton, M. Q. (1987). How to use qualitative methods in evaluation. Newbury Park: SAGE.

Saban, A. (2009). Öğretmen adaylarının öğrenci kavramına ilişkin sahip oldukları zihinsel imgeler. Türk Eğitim Bilimleri Dergisi, 7(2), 281-326.

Steger, T. (2007). The stories metaphors tell: Metaphors as a tool to decipher tacit aspects in narratives. Field Methods, 19(3), 1-22.

Şaban, A. ve Koçbekir, B.N. (2006). Öğretmen adaylarının öğretmen kavramına ilişkin algılarının metafor analizi yoluyla incelenmesi. Kuram ve Uygulamada Ĕgitim Bilimleri, 6(2) 461-522.

Talim ve Terbiye Kurulu Başkanlığı. (2010). İlköğretim Sosyal Bilgiler dersi 4, 5, 6, 7 ve 8. sınıflar öğretim programı. 5 Şubat 2013 tarihinde http://ttkb.meb.gov.tr/www/ogretimprogramlari/icerik/72 sayfasından erişilmiştir.

Tulunay Ateş, Ö. (2016). Öğrencilerin öğretmen ve okul metaforları. International Journal of Contemporary Educational Studies (IntJCES), 2(1), 78-93.

Türk Dil Kurumu. (2011). Türkçe Sözlük, 11.bask1, s. 487, Ankara.

Ulu Kalın, Ö., ve Koçoğlu, E. (2017). Sosyal Bilgiler öğretmen adaylarının bağımsızlık değerine karşı metaforik alg1lar1. Journal of Kirsehir Education Faculty, 18(2), 419-434.

Uzunöz, A., Aktepe, V. ve Köybaş1, E. (2018). Değer analizi yoluyla dürüstlük değerine yönelik öğrenci cevaplarının incelenmesi. Kuramsal Ĕ̈itim Bilimleri Dergisi, 11(3), 606-626. 
Yalman, E., Aktepe, V. ve Uzunöz, A. (2018). Ahlaki ikilem tekniğine dayalı çalışma yaprağına ilişskin 7. sınıf öğrencilerinin görüşleri: farklılıklara saygı değeri. Muş Alparaslan Üniversitesi Sosyal Bilimler Dergisi, 6(3), 413-420.

Yıldırım, A. ve Şimşek, H. (2006). Sosyal bilimlerde nitel araştırma yöntemleri (6. Baskı). Ankara: Seçkin Yayınevi.

Yiğittir S. ve Kaymakçı, S. (2012). Sosyal Bilgiler dersi öğretim programı uygulama kılavuzunda yer alan etkinliklerin değer eğitimi yaklaşımları açısından incelenmesi. Kırşehir Eğitim Fakültesi Dergisi, 13(2), 76-93. 


\section{Extended Abstract}

\section{Introduction}

The main purpose of the education is to educate individuals who are well-equipped and assimilate the values of the society they grow up to and to contribute to the welfare and peace of the society. In order to gain the value of diligence in educational programs, it is necessary to cooperate in a way that aims to create a unity of purpose in addition to programmed learning. As an institution, the schools aim to ensure that the students grow up as active individuals with values starting from the classroom, at the school, within the family, in the neighborhood and in the society, based on the understanding that the student is unique in terms of interests and abilities. The benefit of values for the individual and the society is the basic expectation of the values education approaches in the social studies curriculum. Because it is difficult to identify the problems of the individuals without paying attention to the thoughts or perceptions of the individuals about the values to be gained, to understand these problems and to produce solutions to these problems. Although there are many teaching techniques in order to determine the interests and needs of the students in gaining more effective values in the curriculum, the metaphor technique is important for revealing students' perceptions about values. Using metaphors, students choose a way to explain a concept (value) that they know better by using objects and objects. The views of the students who are stakeholders and the objects of education about values will provide projections to decisions and implementations about the education system. For this reason, the aim of this study is to determine the metaphoric perceptions of secondary school students regarding the value of "diligence" in the social studies curriculum and whether these metaphors differ according to grade levels and gender.

\section{Methods}

In this research, "Phenomenology", one of the qualitative research designs, was used. Phenomenology pattern focuses on cases that we are aware, but we do not have in-depth and detailed understanding. The metaphoric perceptions of the 5th, 6th, 7th and 8th grade students regarding the value of diligence included in the social studies teaching program were determined through content analysis. In the opinions of 5th, 6th, 7th and 8th grade students towards this concept of "Diligence is .......; because......." . Categories were tried to be formed based on the expression forms in their explanations.

\section{Results}

The data obtained for the value of diligence are considered in four categories. The categories formed for the value of diligence; "Struggle, expectation, responsibility, being planned and order'. In the struggle category regarding the value of diligence, students are associated with hard work, struggle, the people working hard without being tired, doing their own work, being as successful as you are struggling, being reliable, preparing for the future, constantly thinking about new things, requiring patience and being determined. It requires good work and labor, requires good education, career planning based on ideas such as the need to do in advance. In the category of expectation regarding the value of diligence, students are associated with expectation, of hard work, that the expectation is to do something for the country, to educate oneself, to produce something, to be a good person for his homeland, to develop a sense of duty, to have a profession that it is to renew itself, to prepare for both this world and the hereafter and to be patient. In the responsibility category regarding the value of diligence, it is observed that students are associated with diligence and responsibility based on knowledgeable, responsible, intelligent and valued. It is also emphasized that responsibility will make an individual mature and tolerant. In the category of being planned and order regarding the value of diligence, students are associated with "Being Planned and Order", where the planned people act with rules, they are organized, they can do teamwork, they are compatible, they will be respected by everyone because they are successful in their environment. It is seen that people are successful in 
their environment, people are appreciated for their planned work, they are honored, they are based on the ideas that planned employees can be comfortable in the future.

\section{Discussion and Suggestions}

The metaphors were evaluated by the researchers in four categories. A total of 136 students expressed their opinions, and 68 metaphors were produced when the categories were created. When the answers given by the students as a metaphoric perception were examined, it was found that boys reported 68 metaphoric views, and girls reported 68 metaphoric views. When we look at the metaphoric perceptions of the female and male students according to their grades, it is noteworthy that male students form more opinions in the fifth grade. It is seen that female students form more metaphors than male students in the sixth grade. It has been determined that male and female students form metaphors that are close to each other and almost the same number in the seventh and eighth grades. It is seen that there are differences in grade levels in the perceptions of the $5^{\text {th }}, 6^{\text {th }}, 7^{\text {th }}$ and $8^{\text {th }}$ grade students about the diligence value. We can say that the fifth and the sixth grade students use concrete names (bee, world, ant, mother and father, book, sun) while creating metaphors. It is seen that the seventh and the eighth grade students create metaphors using abstract concepts (perseverance, honesty, success, talent, profession, smartness) in a remarkable way.

- In addition to verbal expressions about the value of diligence, teachers should include concrete examples, and they can be recommended to strengthen their composition-type written expression.

- The value of diligence can be emphasized not only in social studies courses, but also in other courses.

- In the studies conducted within the scope of values education; drama, painting, shape, graphic studies should be carried out;

- At least one of the texts prepared for achievements in other courses, especially in Social Studies, can be used for the value of diligence. 